\title{
PROTECTIVE EFFECT OF GARCINIA PEDUNCULATA FRUIT RIND IN ACETIC ACID INDUCED ULCERATIVE COLITIS
}

\author{
RAVI MUNDUGARU ${ }^{1}$, PADMAJA UDAYKUMAR ${ }^{2}$, SUNIL KUMAR KN ${ }^{3}$, SHIVANADA \\ NAYAK $^{4}$, THOMAS JACOB ${ }^{5 *}$, ALFARHAN AH ${ }^{5}$, RAJAKRISHNAN R ${ }^{5}$ \\ ${ }^{I}$ Department of Pharmacology and Pharmacognosy, SDM Centre for Research in Ayurveda and Allied Sciences, Kuthpady, \\ Udupi-574118. India \\ ${ }^{2}$ Department of Pharmacology, Father Muller Medical College, Mangalore 575002, India \\ ${ }^{3}$ Research Officer (Pharmacognosy), Siddha Central Research Institute, Central Council for Research in Siddha, Ministry of \\ AYUSH - Govt. of India, Chennai 60010, India \\ ${ }^{4}$ Graduate Studies and Research, Faculty of Medical Sciences, University of the West Indies, Trinidad and Tobago \\ ${ }^{5}$ Department of Botany and Microbiology, College of Science, King Saud University, P.O. Box 2455, Riyadh 11451, Saudi Arabia
}

*corresponding author: jathomas@ksu.edu.sa

Manuscript received: September 2016

\begin{abstract}
Inflammatory bowel disease is an idiopathic, immune mediated and chronic inflammatory condition of intestine. The objective of the present study was to elucidate the protective effect of aqueous extract of fruits of Garcinia pedunculata (AEGP) in acetic acid induced ulcerative colitis in Swiss albino mice. The mice were grouped into four different categories each with six mice. The acetic acid induced colitis was assessed by measuring macroscopic damage score as well as biochemical and histological changes in colon tissue after 7 days of treatment regimen. Administration of AEGP at $400 \mathrm{mg} / \mathrm{kg}$ exhibited significant effect in lowering acetic acid induced macroscopic damage score, lipid peroxidation and histopathalogical changes in colon tissue. The results suggest that the aqueous extracts of fruits of Garcinia pedunculata have ameliorating effect on experimental colitis by enhancing cytoprotective activity.
\end{abstract}

\section{Rezumat}

Boala inflamatorie intestinală este o afecțiune idiopatică, autoimună și cronică. Obiectivul prezentului studiu a fost elucidarea efectului protector al extractului apos de fructe de Garcinia pedunculata (AEGP) în colita ulceroasă indusă de acid acetic la soareci. Animalele au fost distribuite în patru loturi, fiecare cu șase şoareci. Colita indusă de acid acetic a fost evaluată prin măsurarea scorului macroscopic al deteriorării, precum și a modificărilor biochimice și histologice ale colonului după 7 zile de administrare. Tratamentul cu AEGP, în doză de $400 \mathrm{mg} / \mathrm{kgc}$, a diminuat semnificativ scorul macroscopic de deteriorare, precum şi peroxidarea lipidică și a ameliorat modificările histopatalogice ale colonului. Rezultatele sugerează că extractele apoase din fructe de Garcinia pedunculata au ameliorant simptomele colitei indusă experimental prin creșterea activității citoprotectoare.

Keywords: acetic acid, inflammatory bowel disease, lipid peroxidation, macroscopic damaging score

\section{Introduction}

Inflammatory bowel disease (IBD) is a chronic, relapsing inflammatory disorder of gastrointestinal tract. It can be clinically characterized by diarrhea, abdominal pain, weight loss, nausea and with pathological features such as loss of mucosal integrity, infiltration of inflammatory cells [3]. The exact pathology of IBD is uncertain, but the condition seems to be combination of genetic, environmental and immunological factors. There are two subtypes of IBD; ulcerative colitis and Crohn's disease. It is more common in industrialized countries and in urban populations rather than rural areas [24]. Ulcerative colitis mainly confined to the colon and rectum of gastrointestinal tract. It is believed that in ulcerative colitis there is a severe oxidative stress followed by increased production of reactive oxygen species in the mucosal cell lines [7]. This leads to increased lipid peroxidation of cellular membrane followed by release of inflammatory cytokines such as TNF$\alpha$, IL-6, IL-1 $\beta$, which triggers inflammatory condition in IBD [5]. Thus the medication that has the ability to inhibit the production of inflammatory cytokines and good antioxidant property might have role in the treatment of IBD. There are wide range of drugs used in IBD, such as immunomodulators, aminosalicylates, glucocorticoids and sulfasalzines, but these drugs are sometime ineffective and associated with unacceptable adverse effects [1].

Herbs are considered as important source of drugs in different traditional systems of medicines across the world. It is considered relatively safer and cause less side effects. Medicinal plants are rich sources of therapeutically diverse molecules and possess powerful antioxidant and anti-inflammatory chemicals. Many herbs such as Curcuma longa, Zingiber officinale, Zataria multiflora and Camellia 
FARMACIA, 2019, Vol. 67, 1

sinensis, Aloe vera were screened for its use in ulcerative colitis [2].

The dried fruit rind of Garcinia pedunculata has great medicinal value and used in Ayurveda as 'Amlavethasa'. The dried pericarps of the fruits are extensively used in diet by tribes across the northeastern states of India [10]. It is an excellent cardio tonic, rejuvenator, laxative and it is used in cough, asthma, obesity and arthritis [8].The phytochemical studies has shown that the dried fruit rinds contains the following chemicals such as (-) hydroxyl citric acid, benzopheneones, garcinol, pedunculol and combogenn [21]. It has been screened for different activities and reported the following pharmacological activities such as antiinflammatory, hepatoprotective, cardio-protective and in vitro antioxidant activities [17-19]. Based on the earlier study reports Garcinia pedunculata has strong anti-inflammatory, anti-oxidant and cytoprotective activity and hence the present study was aimed to screen the protective effect of AEGP in acetic acid induced ulcerative colitis in Swiss albino mice.

\section{Materials \& methods}

\section{Chemicals}

Acetic acid 99\% (Avra Synthesis Pvt. Ltd. Hyderabad, India), 5,5 dithio-bis 2-nitrobenzoic acid (DTNB), reduced glutathione, thiobarbituric acid, EDTA (HIMEDIA Laboratories Pvt. Ltd., Mumbai, India) All other chemicals and reagents used were of analytical grade.

Plant material

Fruit rinds of Garcinia pedunculata were collected from Assam, India during the month of April 2015. It was authenticated by taxonomists at the Herbarium (KSU), King Saud University, Riyadh and the voucher specimen (KSU-9178) has been deposited for future reference.

Extraction

The fruit rinds were shade dried and powdered at SDM Pharmacy, Udupi. The powder obtained from a single batch was used throughout the study. Powder weighing to $500 \mathrm{~g}$ was soaked in $2 \mathrm{~L}$ of ethanol for $24 \mathrm{~h}$ was filtered and concentrated by evaporation. The concentrated extract was used for present study.

Experimental animals

Swiss albino mice weighing $30-35 \mathrm{~g}$ body weight were used in the present study. Animals were procured from animal house attached to the department of Pharmacology \& Toxicology SDM Centre for research in Ayurveda and Allied Sciences Udupi, India. The Institutional Animal Ethical Committee has approved for experimentation on animals with the reference no SDMCRA/IAEC/SDM/RC 20. Animals were maintained at standard laboratory conditions such as temperature at $25-27^{0} \mathrm{C}$, humidity of $50-55 \%$ and
$12 \mathrm{~h}$ light and dark cycles. Animals were maintained with normal rat diet and water ad libitum.

Acute toxicity test

The acute oral toxicity study was carried out in mice as per OECD guidelines 425. The aqueous extract of fruit rinds of Garcinia pedunculata (AEGP) was made into a suspension in $0.5 \%$ Carboxy methyl cellulose and dosed in the following order 175,550 , and $2000 \mathrm{mg} / \mathrm{kg}$ body weight. The behaviour and mortality of the animals were observed for 14 days to check the safety of AEGP.

Acetic acid induced ulcerative colitis

Selected Swiss albino mice were divided into 4 different groups, each with six mice. Group I animals received only vehicle $(0.5 \%$ Carboxy methyl cellulose) served as normal control, Group II animals received the vehicle $(0.5 \% \mathrm{CMC})$ and considered as colitis control, Group III \& IV were treated with $200 \& 400 \mathrm{mg} / \mathrm{kg}$ body weight of AEGP respectively. All these groups were treated with group specific drugs for 7 consecutive days using oral gavage. On the $4^{\text {th }}$ day after treatment, all the mice were kept for fasting with free access to drinking water. On $5^{\text {th }}$ day, an hour after treatment with group specific drugs, the animals within the groups II, III \& IV were anesthetized by Ketamine \& Xylazine $(80 \mathrm{mg} / \mathrm{kg} \quad \& \quad 3 \mathrm{mg} / \mathrm{kg})$. An infant feeding tube with $2 \mathrm{~mm}$ external diameter was inserted $3 \mathrm{~cm}$ into the colon. A solution of $0.1 \mathrm{~mL}$ of acetic acid $(6 \%)$ solution in $0.9 \%$ saline was instilled into the lumen of colon and maintained in supine trendaleneburg position for 30 seconds to prevent the leakage of intracolonic instillate. The animals in Group I were intracolonic instilled with $0.9 \%$ normal saline. Four days of pre-treatment and three days of post treatment was given to preconditioning in order to prevent the acetic acid induced progressive tissue damage. Animals were sacrificed on $7^{\text {th }}$ day an hour after treatment and colon was dissected out and cleaned with slow running saline to prevent mechanical damage to the colon tissue. The excised colon tissue $5 \mathrm{~cm}$ long was used for macroscopic damage scoring, antioxidant activity and histopathalogical examination [9].

Macroscopic damage score

The colon was rapidly excised, opened along its anti-mesenteric border, gently rinsed of its luminal contents with saline solution and immediately examined macroscopically with naked eyes. Severity of ulceration and damage were noted. By this, extent of damage can be understood by looking into the extent of area inflamed. Lesser extent of inflammation suggests cyto-protective action of test drug. The macroscopic scoring was carried out in the following pattern: normal tissue counted as 0 point, $1-5 \%$ affected area as 1 point, 5$10 \%$ as 2 points, $10-25 \%$ as 3 points, $25-50 \%$ as 4 points, $50-75 \%$ as 5 points and $75-100 \%$ as 6 points respectively [23]. 
Preparation of colon tissue homogenate

The excised colon tissue was cleaned with ice-cold saline and stored in $-20{ }^{0} \mathrm{C}$ in freezer. Tissue was thawed and homogenized in phosphate buffer saline $\mathrm{pH} 7.4$, centrifuged at $4^{0} \mathrm{C}$ and supernatant was stored at $-20{ }^{\circ} \mathrm{C}$. The homogenate was subjected to determine catalase, glutathione peroxidase and lipid peroxidation using standard protocols.

Determination of catalase activity in colon tissue homogenate

The tissue homogenate of $1 \mathrm{~mL}$ volume was taken in $5 \mathrm{~mL}$ of phosphate buffer, to this $4 \mathrm{~mL}$ of $0.2 \mathrm{M}$ $\mathrm{H}_{2} \mathrm{O}_{2}$ in phosphate buffer was added and time was noted. Exactly after 180 seconds of adding $\mathrm{H}_{2} \mathrm{O}_{2}$, a set of $1 \mathrm{~mL}$ of reaction mixture from the above was taken in $2 \mathrm{~mL}$ dichromate acetic acid. It was kept in boiling water bath for 10 minutes, cooled all the tubes under running tap water and finally reading was taken at $570 \mathrm{~nm}$ against reagent blank. Catalase activity in the tissue was expressed as $\mu$ moles $\mathrm{H}_{2} \mathrm{O}_{2}$ consumed $/ \mathrm{mg}$ protein $/ \mathrm{min}$ [22].

Determination of lipid peroxidation activity in colon tissue homogenate

Lipid peroxidation activity was determined by measuring the content of the Thio-barbituric acid reactive substances (TBARs) following the procedure of Ohkawa et al., 1979. Level of lipid peroxidation was expressed as mmoles of MDA formed per $\mathrm{g}$ wet colon tissue [16].

Determination of Glutathione peroxidase activity in colon tissue homogenate

Glutathione peroxidase was estimated by a standard protocol [20]. The glutathione peroxidase activity is expressed as $\mu \mathrm{M}$ of glutathione utilized per mg protein per minute at $37^{\circ} \mathrm{C}$.

Histopathology of colon tissue

After excision of colon tissue immediately transferred into $10 \%$ formalin solution. Sections of less than $5 \mu \mathrm{m}$ thickness of tissue were prepared using microtome and stained with haematoxyline and eosin for microscopic observations [4].All slides were then evaluated under light microscope (ZEISS Axio lab A1 India).

Statistical analysis

The obtained data were expressed as Mean \pm SEM and analyzed by one-way ANOVA followed by Dunnet's multiple t-test, using Graph Pad Prism 3. A $p<0.05$ was considered as statistically significant.

\section{Results and Discussion}

Acute oral toxicity studies

AEGP at doses of $175 \mathrm{mg} / \mathrm{kg}, 550 \mathrm{mg} / \mathrm{kg}$ and 2000 $\mathrm{mg} / \mathrm{kg}$ by oral gavage did not reveal any adverse effects or signs of toxicity in Swiss Albino mice. Daily observations for 14 days have not shown any observable changes or mortality. Accordingly, the acute oral LD50 of the extractives was concluded to exceed $2000 \mathrm{mg} / \mathrm{kg}$ body weight, the highest dose tested in the study.

Macroscopic damage score

Intra rectal instillation of acetic acid caused severe macroscopic damage such as oedematous inflammation in colon. The macroscopic damage score of colitis control group significantly increased as compared to normal control. Aqueous extract of fruits of G. pedunculata treated at $200 \& 400 \mathrm{mg} / \mathrm{kg}$ body weight showed significant reduction in the damage score (Table I). Colitis control has shown significant increase in the concentration of MDA and non-significant decrease in the catalase activity as compared to the normal control group. AEGP administered at a dose $400 \mathrm{mg} / \mathrm{kg}$ body was significantly reversed lipid peroxidation and has shown significant elevation in the catalase activity as compared to colitis control (Table II).

Effect of Aqueous extract of fruits of Garcinia pedunculata on macroscopic score in acetic acid induced ulcerative colitis Groups Macroscopic score

\begin{tabular}{ll}
\hline Normal control & No damage \\
Acetic acid Control & $4.8 \pm 0.37$ \\
AEGP $200 \mathrm{mg} / \mathrm{kg}+$ Acetic acid & $3 \pm 0.31^{\# \#}$ \\
AEGP $400 \mathrm{mg} / \mathrm{kg}+$ Acetic acid & $1.6 \pm 0.24^{\# \#}$ \\
\hline
\end{tabular}

Data expressed as Mean $\pm \mathrm{SEM}, * * \mathrm{p}<0.01, \# \#$ in comparison to acetic acid control

Table II

Effect of Aqueous extract of fruits of Garcinia pedunculata on antioxidant parameters in acetic acid induced Ulcerative colitis

\begin{tabular}{llll}
\hline \multicolumn{1}{c}{ Groups } & \multicolumn{1}{c}{ Catalase $^{\mathbf{1}}$} & \multicolumn{1}{c}{ Glutathione peroxidase $^{2}$} & \multicolumn{1}{c}{ Lipid peroxidation $^{\mathbf{3}}$} \\
\hline Normal control & $38.77 \pm 5.04$ & $2338.59 \pm 380.43$ & $2253.18 \pm 196.66$ \\
Acetic acid Control & $26.67 \pm 3.58$ & $3313.37 \pm 656.95$ & $4155.65 \pm 847.11^{@}$ \\
AEGP 200 mg/kg + acetic acid & $35.54 \pm 3.043$ & $2991.79 \pm 715.61$ & $2709.58 \pm 356.43$ \\
AEGP 400 mg/kg + acetic acid & $99.81 \pm 5.56^{\# \#}$ & $3954.54 \pm 831.67$ & $225.19 \pm 33.58^{\# \#}$ \\
\hline
\end{tabular}

Data expressed as Mean $\pm \mathrm{SEM},{ }^{*} \mathrm{P}<0.05,{ }^{* *} \mathrm{P}<0.01,{ }^{\circ}$ in comparison to normal control group, ${ }^{\# \#} \mathrm{p}<0.01$ in comparison to acetic acid control. ${ }^{1} \mu \mathrm{moles} / \mathrm{min} / \mathrm{mg}$ protein; ${ }^{2} \mu$ moles of glutathione/mg protein for $10 \mathrm{~min} ;{ }^{3} \mu$ moles of MDA formed $/ \mathrm{g}$ wet tissue. AEGP - Aqueous extract of fruits of Garcinia pedunculata

Histopathology

Colon sections from normal control mice exhibited normal cytoarchitecture in the form of welldeveloped epithelial layer with intact crypts; presence of many goblet cells in the goblet pit. In colitis control acetic acid administration lead to transmural necrosis, sub-mucosal oedema, inflammatory cell infiltration in the mucosa, drastic 
loss of epithelium and wall thinning were observed. AEGP at both the doses markedly attenuated the acetic acid induced changes in dose dependent manner. The epithelium was intact with few cells of inflammation; sub-mucosal oedema was minimum,

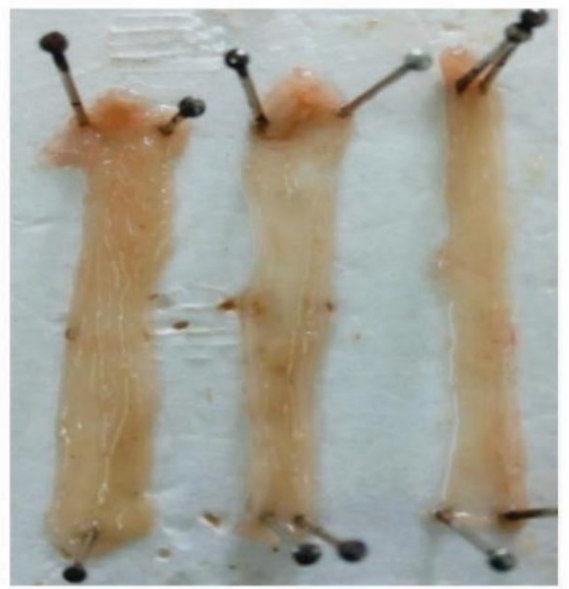

A

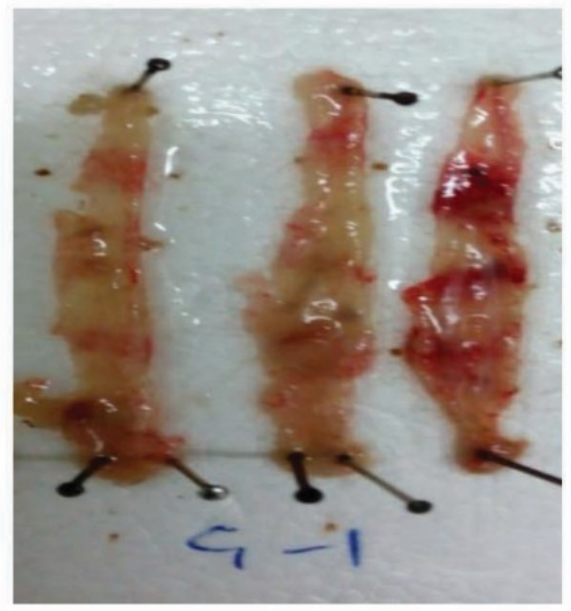

$\mathrm{C}$ cryptal organization was also found to be intact. The protective effect was found to be better at higher dose in comparison to sections from lower dose group (Figures 1 and 2).

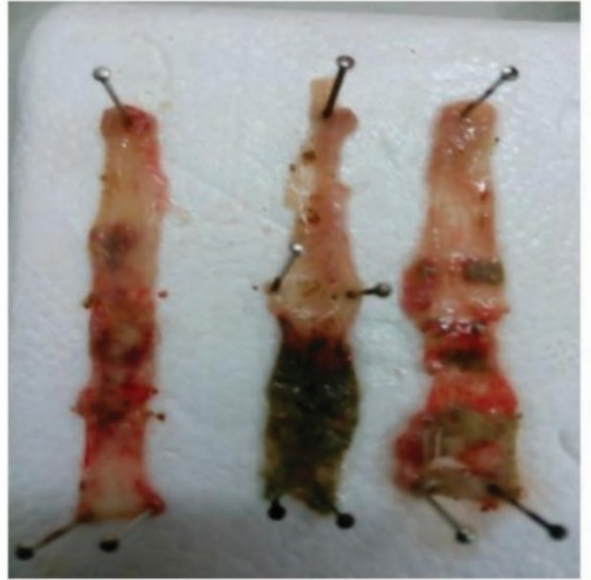

B

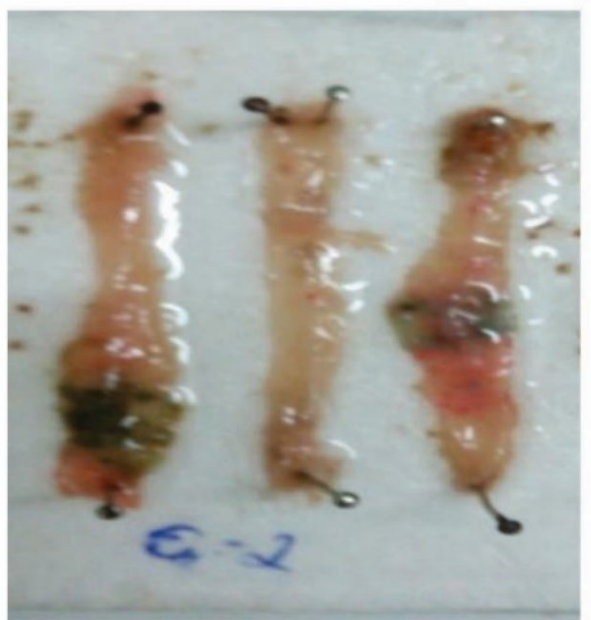

$\mathrm{D}$

Figure 1

Acetic acid induced inflammatory bowel disease in colon of Swiss albino mice. A- Normal control, B- Acetic acid control, C- AEGP $(200 \mathrm{mg} / \mathrm{kg})$,

D- AEGP $(400 \mathrm{mg} / \mathrm{kg})$

Intra rectal instillation of acetic acid can readily cause inflammatory changes such as increased neutrophils infiltration into the colon tissue, massive mucosal necrosis, sub mucosal layer, vascular dilatation and sub mucosal ulcerations. These characteristics having great resembles to human pathogenesis of IBD. It is reported that the protonated form of acid readily liberates protons within the intracellular space and causes massive intracellular acidification leading to epithelial damage [6, 15].

The severe oxidative stress and production of reactive oxygen species such as superoxide anion, hydrogen peroxide, hypochloric acid and hydroxyl radical also plays a critical role in the initiation and progression of inflammation in the inflammatory bowel disease [12, 14]. 

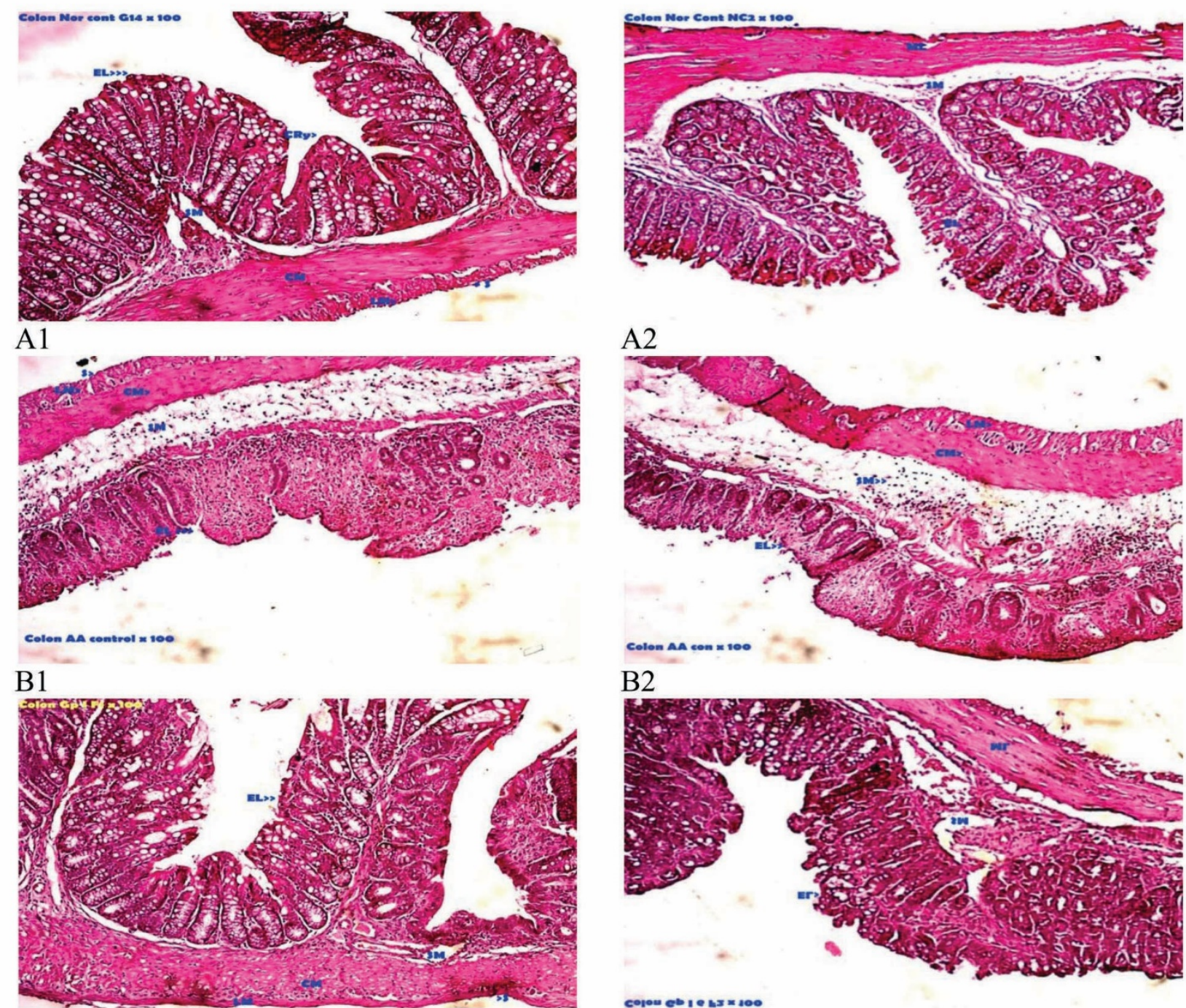

B2
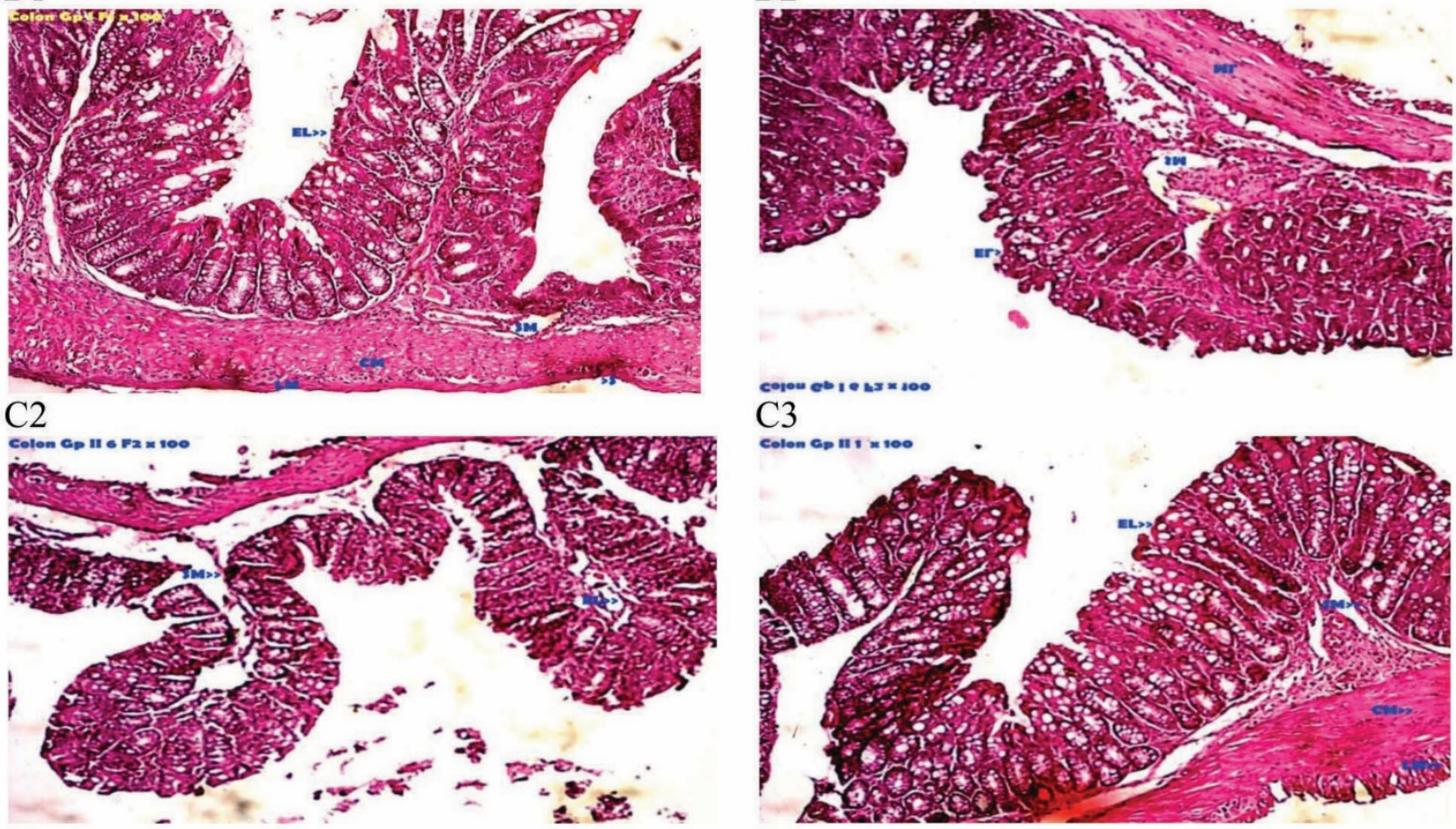

D1

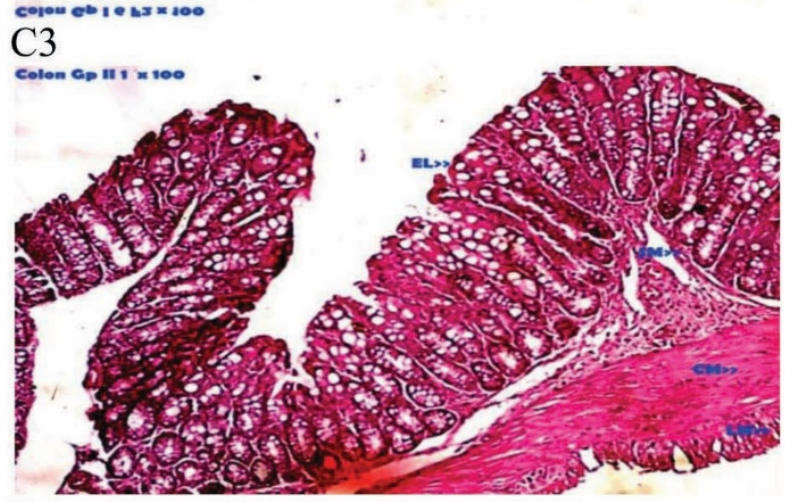

D2

Figure 2

Photomicroph representative of colon sections of Normal control group (A1 \&A2), Colitis control group (B1 \& B2), AEGP $(200 \mathrm{mg} / \mathrm{kg})$ administered group (C1 \&C2), AEGP (400mg/kg) administered group (D1 \&D2) of Swiss albino mice.

The aqueous extract of fruits of $G$. pedunculata (AEGP) has shown improvement in various parameters of acetic acid induced colonic inflammation i.e., macroscopic damage score, lipid peroxidation and histopathalogical examination of colon tissue. In order to counteract reactive oxygen species normally cells has non enzyme and enzymatic mediators. Non enzymatic molecules are glutathione, thioredoxine and thiol containing molecules, whereas enzymes such as superoxide dismutase (SOD), catalase (CAT) and glutathione peroxidase (GSH-Px). SOD is considered as a first defensive enzyme against superoxide and it converts superoxide anions to hydrogen peroxide and oxygen. The generated hydrogen peroxide should be efficiently neutralized by CAT and GSH- 
Px. Thus these enzymes protect the cells from damaging aggressive hydroxyl radicals [13].

Malonaldehyde is a major end product of lipid peroxidation. Increase in the MDA concentration may contribute to increase free radical generation and decreased activity of antioxidant defence system [13]. In the present study the acetic acid administration significantly damaged the epithelial cell line of colon tissue and leads to increased levels of lipid peroxidation. Acetic acid caused oxidative stress and cellular damage to produce toxic colitis. Pre-treatment with higher dose of AEGP significantly prevented lipid peroxidation as compared to acetic acid control.

SOD is a metalloproteinase that catalyses the dismutation of superoxide radicals to form hydrogen peroxide and molecular oxygen. Thus decrease in the activity of SOD and Catalase might be due to increased generation of reactive oxygen species [11].

In the present study there was considerable decrease in the catalase activity in acetic acid control as compared to control. AEGP administered at both dose level exhibited considerable increase in the catalase activity as compared to acetic acid control. It has been reported that the medical plants such as Curcuma longa, Zingiber officinale, Zataria multiflora and Aloe vera possess strong anti-oxidant activity that significantly attenuated the oxidative stress in the inflammatory bowel disease. Thus our findings in the present study support the antioxidant potential of test drug to prevent the oxidative stress induced by acetic acid on colon tissue [6].

Histopathological findings also support the general cytoprotective action of AEGP. Acetic acid control group mice have shown sub-mucosal oedema, infiltration of inflammatory cells, loss of epithelium and wall thinning were observed. Whereas the AEGP administered at higher dose were significantly reversed the inflammatory pathological signs induced by acetic acid.

\section{Conclusions}

The results of the present study confirm the traditional indications of Garcinia pedunculata and present a new therapeutic option for the treatment of colitis. It has exhibited good antioxidant and anti-inflammatory properties which would be the responsible factor in the protection against the acetic acid induced colonic damage.

\section{Acknowledgement}

The authors would like to extend their sincere appreciation to the Deanship of scientific Research at King Saud University for funding this research (RG-1437-002).

\section{References}

1. Alberto B, Marco Z, Stefano C, Albert T, Ettore $\mathrm{CA}$, Alessandro F, Surgical treatment of ulcerative colitis in the biologic therapy era. World $J$ Gastroenterol., 2012; 28: 1861-1870.

2. Awad AS, El-Meligi RM, Solimen GA, Natural product in the treatment of ulcerative colitis and gastric ulcer. Saudi Chem Soc., 2013; 17: 101.

3. Bamgart DC, Carding SR, Inflammatory bowel disease cause and immunobiology. Lancet, 2007; 369:1627.

4. Bancroft JD, Gamble M, Theory and practice of histological techniques. Churchill Livingstone, 2002.

5. Closa D, Folch-Puy E, Oxygen free radicals and the systemic inflammatory response. IUBMB Life, 2004; 56: 185-191.

6. Grisham MB, Granger DN, Neutrophil-mediated mucosal injury. Role of reactive oxygen metabolites. Dig Dis Sci., 1988; 33: 6-15.

7. Hartmann RM, Morgan Martins MI, Tieppo J, Fillmann HS, Marroni NP, Effect of Boswellia serrata on antioxidant status in an experimental model of colitis rats induced by acetic acid. Dig Dis Sci., 2012; 57: 2038-2044.

8. Jayaprakasha GK, Negi PS, Jena BS, Antioxidative and antimutagenic activities of the extracts from the rinds of Garcinia pedunculata. Innovative Food Science \& Emerging Technologies, 2006; 7: 246250.

9. Jurjus AR, Khoury NN, Reimund JM, Animal models of inflammatory bowel disease. $J$ Pharmacol Toxicol Methods., 2004; 50: 81-92.

10. Kagyung R, Gajurel PR, Rethy P, Singh B, Ethnomedicinal plants used for gastrointestinal diseases by Adi tribes of Dehang-Debang Biosphere Reserve in Arunachal Pradesh. Indian journal of traditional knowledge, 2010; 9: 496-501.

11. Kannan N, Guruvayoorappan C, Protective effect of Bouhinia tomentosa on acetic acid induced ulcerative colitis by regulating antioxidant and antiinflammatory mediators. Immunopharmacology, 2013; 16: 57-58.

12. Keshavarzian A, Sedghi S, Kanofsky J, List T, Robinson C, Ibrahim C, Winship D, Excessive production of reactive oxygen metabolites by inflamed colon: analysis by chemiluminescence probe. Gastroenterology, 1992; 103: 177-185.

13. Khalid Rehman, Studies on free radicals, antioxidants and cofactors. Clin Interv Aging, 2007; 2: 219-236.

14. Kruidenier L, Verspaget HW, Oxidative stress as a pathogenic factor in inflammatory bowel disease-radicals or ridiculous?. Aliment Pharmacol Ther, 2002; 16: 1997-2015.

15. MacPherson BR, Pfeiffer CJ, Experimental production of diffuse colitis in rats. Digestion, 1978; 17: 135-150.

16. Ohkawa H, Ohishi N, Yagi K, Assay for lipid peroxides in animal tissues by thio-barbituric acid reaction. Anal Biochem, 1997; 95: 351-358.

17. Ravi M, Febin J, Shrinidhi R, Lipika D, Sudhakara B, Ravishankar B, Anti-inflammatory activity of 
aqueous extract of fruits of Garcinia pedunculata in experimental animals. Am J Pharma Tech Research, 2014; 4: 3-6.

18. Ravi M, Madhan C, Ravishankar B, Hepatoprotective activity of fruits extract of Garcinia pedunculata. Bangladesh $J$ of Pharmacol., 2014; 9: 4-8.

19. Ravi M, Senthilkumar S, Padmaja UK, Sudhakara B, Cardio protective activity of fruits extract of Garcinia pedunculata. Bangladesh $J$ of Pharmacol., 2016; 11: 5-9.

20. Rotruck JT, Pope AL, Ganther HE, Swanson AB, Hafeman DG, Hoekstra WG, Selenium: biochemical role as a component of glutathione peroxidase. Science., 1973; 179: 588-590.

21. Sahu A, Das B, Chatterjee A, Polyisoprenylated benzophenones from Garcinia pedunculata. Phytochemistry, 1989; 28(4): 1233-1235.

22. Sinha KA, Colorimetric assay of catalase. Anal Biochem., 1972; 47: 389-394.

23. Thippeswamy BS, Mahendran S, Biradar MI, Badami S, Protective effect of embelin against acetic acid induced ulcerative colitis in rats. Eur $J$ Pharmacol, 2011; 654(1): 100-105

24. Thoreson R, Cullen JJ, Pathophysiology of inflammatory bowel disease: an overview. Surg Clin North Am., 2007; 87(3): 575-585. 